\title{
Cooperation and Litigation: Thoughts on the American Experience
}

\author{
Richard Marcus*
}

Contemporary German civil process is cooperative. It facilitates reaching judgments quickly and cheaply based on substantive truth and law. It is an explicit rejection of process that predated the Code of Civil Procedure in 1877, which had been based, like American process still is, on a kind of "battle-between-the-parties" model.

I grew up in the age of Rambo litigation. ${ }^{2}$ But from what I have read since leaving practice for teaching more than thirty years ago, litigators (and other American lawyers) may well be more adversarial and less cooperative than ever. Some suggest that this tendency results in part from client domination of lawyers. ${ }^{3}$ Far from serving as the learned counselors that Dean Kronman applauded as representative of a lost golden era of lawyering, ${ }^{4}$ today's litigator gets the case by winning a "beauty contest" and remains thereafter under the client's thumb. No longer does the lawyer tell the client what to do in the litigation; the client-implementing a litigation budget-may control the day-to-day details of what the lawyer does. And the client does not want to hire a “cooperator," but rather a bulldog.

\footnotetext{
Horace O. Coil ('57) Chair in Litigation, University of California, Hastings College of the Law. I presented this paper at the Nov. 9, 2012, Kansas Law Review symposium "Advocacy Under the Federal Rules of Civil Procedure After 75 Years.” In part, I drew on my experience since 1996 as Associate Reporter of the Advisory Committee on Civil Rules. In the piece, however, I do not speak for the Committee or for anyone else.

1. James R. Maxeiner, Gyooho Lee \& Armin Weber, Failures of American CiviL Justice In INTERNATIONAL PERSPECTIVE 171 (2011).

2. "Rambo" lawyering is succinctly defined as "attorneys who employ whatever tactics necessary for victory, no matter how repugnant.” Joseph R. Wilbert, Note, Muzzling Rambo Attorneys: Preventing Abusive Witness Coaching by Banning Attorney-Initiated Consultations with Deponents, 21 Geo. J. Legal Ethics 1129, 1129 (2008).

3. See David Luban, Partisanship, Betrayal and Autonomy in the Lawyer-Client Relationship: A Reply to Stephen Ellmann, 90 CoLUM. L. REV. 1004, 1036-37 (1990) (noting "private practitioners depend wholly on their clients for their livelihood, and this dependence is fundamental in the distribution of power.").

4. See generally ANTHONY KRONMAN, THE LOST LAWYER: FAILING IDEALS OF THE LEGAL PROFESSION (1993) (bemoaning the rise of law firms that regard what they do solely as a business focused on the bottom line, and the vanishing age of the lawyer as counselor and guide to the client).
} 
There must be much wrong with this picture, including its accuracy. Even Republican candidates now emphasize their enthusiasm for bipartisan cooperation to overcome voters' dislike for uncooperative legislative posturing. ${ }^{5}$ Surely lawyers are not really so adversarial as portrayed by Hollywood.

American procedure has assumed that, in some ways, they are. But that is not entirely a new thing. Indeed, one of the prime things Roscoe Pound decried in his famous 1906 speech to the American Bar Association (ABA) was the extreme adversarialism of American litigation at that time. ${ }^{6}$ One of his goals was to equip judges to contain and constrain that adversarialness. ${ }^{7}$ The Federal Rules of Civil Procedure, now approaching their seventy-fifth anniversary, were in some ways an effort to move away from the pettifogging adversarial behavior Pound found so lamentable. They sought to replace pleading wars and games with simplified pleading, in some ways realizing the mid-nineteenth century dream of David Dudley Field that pleading niceties would not enable sneaky lawyers to torpedo valid claims. ${ }^{8}$ They introduced broad discovery to enable parties to find out about the evidence and avoid the sort of trial by ambush Pound described. ${ }^{9}$ And they stressed flexibility, with Rule 1 emphasizing from the outset that the rules should be construed to achieve justice.

Rambo tactics are not the only way to achieve justice, perhaps not even a plausible way to do so. I intend to try to introduce the question of cooperation in litigation in three pieces. First, I will try to reflect at a very general level on why we might want litigators to be pretty adversarial, and recoil somewhat at their trying instead to be cooperative. Second, I will sketch very briefly and in great generality the sorts of problems that seem to arise when laws command cooperative behavior,

5. See Jennifer Steinhauer \& Jonathan Weisman, Some Republicans Try Out a New Campaign Theme: Bipartisanship, N.Y. TIMES, Sept. 15, 2012, at A16 (describing campaign ads in which Republican candidates eschewed "partisan obstreperousness" and instead sought to "promote the wonders of bipartisanship").

6. See Roscoe Pound, The Causes of Popular Dissatisfaction With the Administration of Justice, 29 A.B.A. REP. 395, 404-06 (1906) (denouncing "our American exaggerations of the common law contentious procedure.").

7. Id. at 405 (suggesting that the legal system requires judges to be "mere umpires" and avoid judicial interference- a notion that further provokes the contentiousness of adversarial proceedings).

8. See Richard L. Marcus, The Revival of Fact Pleading Under the Federal Rules of Civil Procedure, 86 COLUM. L. REV. 433, 439-40 (1986).

9. See Stephen N. Subrin, Fishing Expeditions Allowed: The Historical Background of the 1938 Federal Discovery Rules, 39 B.C. L. REV. 691, 733-39 (1998) (describing how revolutionary the expansion of discovery in the 1938 Rules really was). 
which should make us cautious about moving too far toward legal commands to cooperate. But these situations are distinguished by the fact that judges ultimately do not have the authority to decide the things on which the law aspires to encourage the parties to cooperate. Finally, I will recognize that twenty-first century litigation-particularly involving e-discovery-makes substantial and substantive cooperation essential and effective. Against that background, it seems that the distinctive thing about the topics on which judges now press for cooperation is that they are matters on which the judge can enter an order resolving the issue if the parties do not agree.

\section{EMBRACING RAMBO: THE LAWYER AS GUARDIAN}

In ordinary life, cooperation is generally valued, and for good reason. If everyone insisted on having everything his own way, ordinary life would not be possible, or at least it would be pretty disagreeable. We even have a term for people who insist on having their own way all the time- "high maintenance." Cooperation and accommodation have been essential to the development of complex societies; the lone cave-dweller might not have needed to worry about what other people wanted, but the modern city-dweller must. Most of the time, no dispute occurs even when people do not get their first choice.

That general attitude of compromise (or at least tolerance) explains something that academics emphasized a generation ago as the alternative dispute resolution (ADR) movement began to attract followers - the low frequency of formal litigation in comparison to the number of disputes that arise in American society. A leading article presented a "dispute pyramid" graphically demonstrating that only a tiny fraction of actual disputes lead to litigation. ${ }^{10}$ These academic presentations were designed to emphasize that-contrary to one theme often sounded in the 1970s and 1980s-Americans are not singularly litigious.

Probably all would agree that it is a good thing Americans are not actually as litigious as some assert they are. The point for our purposes is that sometimes one might think it right for people not to be cooperative, and recognize instead that they should stand and resist

10. See Richard E. Miller \& Austin Sarat, Grievances, Claims, and Disputes: Assessing the Adversary Culture, 15 LAW \& SOC’Y REV. 525, 537 (1981); see also Marc Galanter, Reading the Landscape of Disputes: What We Know and Don't Know (and Think We Know) About Our Allegedly Contentious and Litigious Society, 31 UCLA L. REV. 4 (1984), 11-18 (examining the attrition rate among potential disputes before a third party—such as a lawyer—is called upon). 
accommodating the desires of others. Legal rights, after all, are often designed to protect the less powerful. At a minimum, they may counteract the insistence of some people on having their way. As one scholar put it: "The claim that people have common interests can, moreover, be a way of misleading the less powerful into collaborating with more powerful in schemes that mainly benefit the latter."11

The basic point is that the argument can be made against cooperation, particularly when legal rights are involved and litigation is an option. Thus, Judge Edwards warned against unthinking embrace of ADR during the 1980s:

One essential function of law is to reflect the public resolution of such irreconcilable differences; lawmakers are forced to choose among these differing visions of the public good. A potential danger of ADR is that disputants who seek only understanding and reconciliation may treat as irrelevant the choices made by our lawmakers and may, as a result, ignore public values reflected in rules of law. ${ }^{12}$

At some level, then, we want people to say "no." But we may be concerned that they will find it difficult to do so. To take a recurrent example, many have written about the risk that in marital breakups the dominant partner-often the man - will take advantage of the other spouse. ${ }^{13}$ This is often where lawyers come in-they are, in a real sense, spine-stiffeners. They can tell clients what their legal rights actually are. They can encourage clients to stand up for their rights. They can go into court and seek to vindicate those rights.

Besides these points, in a common law system, the result of private litigation is a body of case law that guides others in their out-of-court interactions. Thus, to some extent we want people to fight through to the end sometimes so that we can get a judicial resolution of a dispute. ${ }^{14}$

11. JANE J. MANSBRIDGE, BEYOND ADVERSARIAL DEMOCRACY 5 (1983)

12. Harry T. Edwards, Alternative Dispute Resolution: Panacea or Anathema?, 99 HARV. L. REV. 668, 679 (1986).

13. See, e.g., Martha Fineman, Dominant Discourse, Professional Language, and Legal Change in Child Custody Decisionmaking, 101 HARV. L. REV. 727 (1988) (arguing that the introduction of social workers as mediating influences in child custody situations has produced a “disaster” imposed on women due to social workers' preference for shared parenting). See generally Trina Grillo, The Mediation Alternative: Process Dangers for Women, 100 YALE L.J. 1545 (1991); Richard Delgado et al., Fairness and Formality: Minimizing the Risk of Prejudice in Alternative Dispute Resolution, 1985 WIS. L. REV. 1359 (1985).

14. See Edward Brunet, Questioning the Quality of Alternative Dispute Resolution, 62 TUL. L. REV. 1, 19-20 (1987) (emphasizing that the absence of judicial decisions could increase disputes because of unresolved issues about what the law requires). 
Indeed, the urge to cooperate may compromise those very legal principles. Consider the attitude of a mediation enthusiast in relation to divorce mediation:

Divorce mediation rejects the idea that legal rules should be used as weapons to improve one party's position at the expense of the other. Similarly, it rejects the idea that these legal rules and principles embody any necessary wisdom or logic. In fact, it views them as being arbitrary principles, having little to do with the realities of a couple's life and not superior to the judgments that the couple could make on their own.

Surely there is a valid argument that lawyers may resist the notion that their clients' legal protections are "arbitrary," and insist on pursuing their clients' legal rights.

That is all heady stuff, the sort of speech lawyers who are enthusiasts for law enforcement through private litigation intone whenever proposals are made to curtail their freedom of action in litigation. But it is also a critical starting point in assessing our commitment to cooperationrecognizing that cases in court represent failures of cooperation in which one side or the other claims that legal rules require an outcome the other side will not accept cooperatively. In a society in which much law enforcement depends on private litigation, there is a public stake in that litigation.

Should lawyers routinely engage in spine-stiffening, encouraging their clients to take the most aggressive stance? Obviously not; at a minimum that stance must be supported by law for a lawyer to endorse it. ${ }^{16}$ So the question is when lawyers should urge clients to compromise, or at least to be collaborative, even though their legal rights support combat.

Perhaps the strongest argument for resolute insistence on the full measure of legal rights exists for the criminal defense lawyer. That lawyer represents somebody_often truly "disempowered"-faced with the full power of the State. For at least some, ${ }^{17}$ that lawyer is duty-bound

15. Lenard Marlow, The Rule of Law in Divorce Mediation, 9 MEdiation Q. 5, 10 (1985).

16. Cf. FED. R. CIV. P. 11(b)(2) (treating a lawyer's signature on a paper filed in court as certifying that the contentions made "are warranted by existing law or by a nonfrivolous argument for extending, modifying, or reversing existing law or for establishing new law").

17. Perhaps the most prominent exponent of this view is Dean Monroe Freedman. See, e.g., Monroe H. Freedman, In Praise of Overzealous Representation-Lying to Judges, Deceiving Third Parties, and Other Ethical Conduct, 34 HofsTRA L. REV. 771, 775 (2006) (exploring the strong version of zealous advocacy in the context of the criminal defendant). 
to consider only her client's interests and to advance them wherever not forbidden to do so.

It may sometimes seem that, for criminal defense lawyers, refusal to cooperate in regard to anything is the order of the day. ${ }^{18}$ If the prosecution is having difficulty locating a witness and the speedy-trial limits on when the case must be brought to trial will shortly expire, could defense counsel justify "cooperating" with the prosecution to enable it to find and present the witness? If the defendant is incompetent to stand trial due to mental illness, should counsel encourage the client to take medication that might overcome the illness? ${ }^{19}$ It sometimes seems that any trick in the book is fair game for the criminal defense lawyer, who may appear to regard her main job as obstructing the prosecution. More than forty years ago, Judge Henry Friendly asked plaintively, "Is Innocence Irrelevant?”20 Maybe it can be for the criminal defense lawyer.

But at the same time, it does not seem that the cooperation movement is nearly as broadly touted for criminal litigation as for civil litigation. One reason might be the absence of something Dean Kronman deplored about the "lost" lawyer ${ }^{21}$ — the much greater client dominance achieved by some private clients, particularly large corporations. The disempowered criminal defendant is not in a similar position to compel his lawyer to do his bidding. Usually that lawyer will be hired by the State, not the defendant. Sometimes, that lawyer can overtly undercut his client's interests in court. ${ }^{22}$

Should lawyers in civil cases adopt a similar "take no prisoners" attitude? At least in some sorts of cases, that seems counterproductive. Family law again presents a good example. Should lawyers encourage divorcing spouses to insist on the full measure of their legal rights and

18. See Peter J. Henning, Lawyers, Truth, and Honesty in Representing Clients, 20 NOTRE DAME J.L. ETHICS \& PUB. POL'Y 209, 210-11 (2006) (discussing how the criminal defense lawyer's paramount obligation obstructs the search for truth in a case).

19. Cf. Sell v. United States, 539 U.S. 166, 169 (2003) (holding that a court may order administration of antipsychotic medication to render the defendant competent to stand trial only under limited circumstances).

20. See generally Henry J. Friendly, Is Innocence Irrelevant? Collateral Attack on Criminal Judgments, 38 U. CHI. L. REV. 142 (1970).

21. See KronMAN, supra note 4, at 284-85 (finding that the increase in specialized big firms decreases lawyer bargaining power).

22. See, e.g., Nix v. Whiteside, 475 U.S. 157, 176 (1986) (holding the Sixth Amendment right to effective assistance of counsel was not violated when defense counsel threatened to withdraw and impeach client's testimony during the murder trial if client insisted on taking stand and committing perjury). 
fight to the bitter end? That bitterness itself might poison the lives of the couple's children, which explains why many states require mediation whenever child custody is at issue in divorce cases. ${ }^{23}$ Indeed, familiar lore has it that lawyers do not often have to encourage their clients to take aggressive stances in divorce cases; to the contrary, they may more often be the ones urging moderation to avoid an outcome like the one in the movie The War of the Roses. ${ }^{24}$

Perhaps it is time for a similar attitude to prevail in all civil litigation. About forty years ago, the federal judiciary took up Dean Pound's cudgel and rejected the extreme adversarial attitude. ${ }^{25}$ One sparkplug was a speech by then-Judge Frankel, urging that the search for truth be elevated to primacy among counsel's obligations. ${ }^{26}$ More generally, federal judges have embraced the case-management movement and striven to regulate lawyer behavior in civil litigation. ${ }^{27}$ This attitude has largely depended on cooperative behavior by the lawyers before them; in the absence of such cooperation, judges may find that they cannot easily design specific directives for given cases. ${ }^{28}$

So we are left with two competing concerns. On the one hand, the desire of litigants for justice-a decision according to governing legal principles - is a justified urge; on the other hand, we must have a realistic appreciation that compromise is a generally desirable thing. Lawyers are likely to find that they are regularly tugged in two directions by these ideals. Judges must similarly keep both in mind.

\section{THE CHALLENGES OF MANDATED COOPERATION}

Appreciating the competing tensions underlying the cooperation debate, one can consider whether cooperation itself should-or couldbecome a mandate. In this section, I hope to present a very brief sketch of several areas of law in which the effort to enforce cooperation has

23. See, e.g., N.C. Gen. StaT. § 50-13.1(c) (2000 \& Supp. 2012); CAL. FAM. CodE § 3170 (West 2004 \& Supp. 2013).

24. A divorcing and cohabitating couple engages in constant quarrel that ultimately results in the death of both parties. THE WAR OF THE ROSES (Twentieth Century Fox Film Corporation 1989).

25. See generally, Roscoe Pound, Improving the Administration of Justice, 29 A.B.A. J. 494, 494 (1943) ("[T]hese are limitations upon law in the sense of the judicial and the administrative processes.”).

26. Marvin E. Frankel, The Search For Truth: An Umpireal View, 123 U. PA. L. Rev. 1031, 1038 (1975).

27. See generally Richard L. Marcus, Reining in the American Litigator: The New Role of American Judges, 27 HASTINGS INT'L \& COMP. L. REV. 3 (2003).

28. Id. at 15 . 
proven difficult for judges. Each of these areas of law must be explored at much greater length to do it any justice, and this presentation will oversimplify and probably distort each of them. But the goal is only to show that the judiciary has experience with the difficulty of enforcing commands to cooperate, and generally shuns them.

\section{A. The Duty of Labor and Management to Bargain in "Good Faith"}

Section 8(a)(5) of the National Labor Relations Act obligates unions and employers to bargain "in good faith." ${ }^{29}$ By so commanding, it was designed to some extent to change the conditions of "industrial warfare" that had prevailed before its adoption. In most instances, that shift would likely have strengthened unions, but it was not designed to require the parties to reach any particular agreement. ${ }^{30}$ An early focus was on mandatory topics of negotiation; neither side could absolutely refuse at least to discuss those topics. ${ }^{31}$ Unions with sufficient power to insist would put additional issues on the table; those who could not would try to persuade the National Labor Relations Board (NLRB) to insist that "good faith bargaining" include consideration of those issues. ${ }^{32}$

Resolving these disputes became a taxing effort a half century ago. The dramatic decline in the power of private sector unions since then gives a somewhat sepia-toned aspect to these disputes, but they still stand as a warning about the utility of governmental regulation of negotiation. Initially, the idea was that the content and outcome of collective bargaining was beyond the authority of government. As the Chairman of the pertinent Senate Committee declared:

When the employees have chosen their organization, when they have selected their representatives, all the bill proposes to do is to escort them to the door of their employer and say, "Here they are, the legal representatives of your employees." What happens behind those doors is not inquired into, and the bill does not seek to inquire into it. ${ }^{33}$

\footnotetext{
29. 29 U.S.C. § 158(a)(5) (2006).

30. Archibald Cox \& John T. Dunlop, Regulation of Collective Bargaining by the National Labor Relations Board, 63 HARV. L. REv. 389, 389-90 (1950).

31. Id. at 393-94.

32. Id. at 391.

33. NLRB v. Ins. Agents' Int'l Union, 361 U.S. 477, 484 (1960) (referencing the statement of Senator Walsh).
} 
But particularly with weaker unions, there was surely a temptation to peek inside the door. After all, one goal of the legislation was to foster labor peace by encouraging collective bargaining agreements. ${ }^{34}$

The Supreme Court recognized that "Congress intended that the parties should have wide latitude in their negotiations, unrestricted by any governmental power to regulate the substantive solution of their differences." 35 But it also recognized that "there is tension between the principle that the parties need not contract on any specific terms and a practical enforcement of the principle that they are bound to deal with each other in a serious attempt to resolve differences and reach a common ground." ${ }^{36}$ One resolution was at least to require flexibility on the various mandatory topics: "A refusal to negotiate in fact as to any subject which is within § 8(d) ... violates § 8(a)(5) though the employer has every desire to reach agreement with the union upon an over-all collective agreement." 37

This set of imperatives presented the NLRB, and also the courts, with a challenging job. How exactly does one assess the "good faith" of the bargaining independent of assessing the propriety of the positions taken by the bargainer? Under the leadership of Lemuel Boulware, General Electric adopted a strategy of relatively overt refusal to comply with the Act. Boulware concluded that the routine negotiating tactics of beginning with an unfavorable proposal that could gradually be improved as negotiations evolved was wasteful and produced imperfect ultimate agreements. $^{38}$ In its place, he concluded that General Electric should make a "fair and firm offer" initially, after much study, and then take the position that it would not change that offer unless the union demonstrated that the offer was based on some sort of mistake of fact. ${ }^{39}$ The union claimed that this violated the duty to negotiate, and the Board so concluded. ${ }^{40}$ It said that GE's “'bargaining' position is akin to that of a party who enters into negotiations 'with a predetermined resolve not to

34. Carey v. Westinghouse Elec. Corp., 375 U.S. 261, 271 (1964) (quoting Int'l Harvester Co., 138 N.L.R.B. 923, 925-26 (1962).

35. Ins. Agents' Int'l Union, 361 U.S. at 488.

36. Id. at 486 .

37. NLRB v. Katz, 369 U.S. 736, 743 (1962).

38. See Gen. Elec. Co., 150 N.L.R.B. 192, 208 (1964) (discussing G.E.'s policy of bargaining where it voluntarily offers what is “'right' for employees”).

39. Id.

40. Id. at 194 . 
budge from an initial position,' an attitude inconsistent with good faith bargaining." 41

Even with such overtly unilateral action, commentators found that the problem was that the Board could not identify any specific action taken by GE that violated the Act. As a consequence:

[T] he GE decision imparts only an exhortation to the GE management to change its frame of mind without necessarily changing any of its actions. How equitable or effective is a decree that offers neither the company nor the union any guide whatever by which to judge the legality of management's future actions? ${ }^{42}$

At least here, the basic problem seems to be the one we started with - the fact that the Board and the courts are not in a position to do more than insist on "good faith bargaining." They cannot impose a solution. But the Act also rather clearly sought to press the parties to resolve their differences at the negotiating table, and probably also sought in general to strengthen unions in their dealings with management. ${ }^{43}$ This led to a "totality of the circumstances" approach to evaluating the parties' (particularly the employer's) conduct, and sometimes could lead the NLRB to denounce attitudes or tactics adopted by parties that seemed unreceptive to reaching a collaborative agreement. $^{44}$ That impulse probably contributed to the NLRB's reputation as a biased union supporter that overstepped its statutory role, thereby engendering the enduring enmity of the business community. ${ }^{45}$ That surely is not a direction courts would want to go.

\section{B. The Relation Between an Insurer and Insured}

In California, every driver is legally required to have liability insurance, and much the same is true in many other states. ${ }^{46}$ To get that

41. Id. at 195-96.

42. James A. Gross, Donald E. Cullen \& Kurt L. Hanslowe, Good Faith in Labor Negotiations: Tests and Remedies, 53 CORNELL L. REV. 1009, 1031 (1968).

43. Id.

44. Id. at 1010-11.

45. See SEAn FARHAng, The Litigation State 211-13 (2010) (explaining that the business community vehemently opposed giving the EEOC enforcement authority of anti-discrimination provisions in Title VII because it feared the EEOC would behave in that sphere as the NLRB had in the labor sphere).

46. See Jennifer B. Wriggins, Automobile Injuries as Injuries with Remedies: Driving, Insurance, Torts, and Changing the "Choice Architecture" of Auto Insurance Pricing, 44 LOY. L.A. L. REV. 69, 74 (2010) (explaining that most states require drivers to purchase liability insurance). 
insurance, drivers must contract with a limited set of insurers, and the relationship is (like the labor-management relationship) closely regulated. ${ }^{47}$ In particular, the conduct of the insurer and the insured when litigation occurs or is threatened gives rise to some distinctive responsibilities. The insurer's responsibilities have generated a whole new species of law - the bad faith refusal to settle a claim. ${ }^{48}$

It can be said that the insurer has a "quasi-fiduciary relationship" with the insured. ${ }^{49}$ As the Colorado Supreme Court has explained: "[T]he duty of good faith derives from the relationship of an insured claimant to the provider of benefits. This relationship, arising from the underlying insurance or compensation obligation ... permeates all the dealings between the parties." ${ }^{\text {}}$ This attitude has even been applied when the insured makes a claim against the insurer under coverage for injuries received from an uninsured motorist, which might seem to place the insured and the insurer in an entirely adverse relationship. ${ }^{51}$

More often, the tension between the insurer and the insured has to do with the "duty to settle" claims brought against the insured for conduct potentially covered by the insurance. There is a potentially adversarial relationship when there is a substantial question about whether the insured is really liable at all and there is also a significant potential that the insured will, if found liable, be held liable for more than the policy limits. In those circumstances, an entirely self-interested insurer might think it worthwhile to resist the claim on the merits, hoping to avoid any liability to indemnify, while the insured might want the insurer to offer the policy limits to settle the whole case, protecting the insured against liability above those limits. That tension is the source of the tort claim for bad faith failure to settle. If the insurer does not settle, and judgment is entered against the insured for more than the policy limits, the insured may have a claim against the insurer. And the plaintiff may be willing to settle with the insured (who thereby protects his other assets) for an assignment of the claim against the insurer. If that claim is successful, it is not subject to the policy limit because, if the insurer had willingly paid

47. See Alma Cohen \& Rajeev Dehejia, The Effect of Automobile Insurance and Accident Liability Laws on Traffic Fatalities, 47 J.L. \& ECON. 357, 361 (2004) (discussing the range of regulation governing automobile insurance and liability).

48. See, e.g., Fortner v. Grange Mut. Ins. Co., 686 S.E.2d 93, 94 (Ga. 2009).

49. Farmers Grp., Inc. v. Trimble, 691 P.2d 1138, 1141 (Colo. 1984).

50. Travelers Ins. Co. v. Savio, 706 P.2d 1258, 1268 (Colo. 1985).

51. But see Seabron v. Am. Family Mut. Ins. Co., 862 F. Supp. 2d 1149 (D. Colo. 2012) (holding that even in this situation the insurer and the insured are not in a "purely adversarial" relationship, and the insurer has a continuing duty to deal in good faith with the insured). 
the policy limit, it could have kept its liability to that limit and also protected the insured.

Charting this set of obligations owed by the insurer to the insured is risky and difficult, as the Ninth Circuit recently found out in a case fitting the model described above. The insured there was involved in a collision in which three people in the other car claimed injury. ${ }^{52}$ The insurer did not take the initiative by making a settlement offer to the lawyer for those three people. ${ }^{53}$ For some time they made no demand on the insurer. ${ }^{54}$ Eventually their lawyer demanded the policy limits$\$ 300,000$ for a single accident—but the insurer did not agree. ${ }^{55}$ Then the most seriously injured plaintiff sued, and eventually won a judgment for more than $\$ 4$ million. ${ }^{56}$ After that, the insured assigned the bad faith claim to the plaintiff, who sued the insurer. ${ }^{57}$ At the trial of that case, the district judge rejected plaintiff's proposed jury instruction that suggested the insurer should have taken the initiative by offering to settle the case rather than awaiting a settlement demand from plaintiff, and the insurer prevailed. On plaintiff's appeal, the Ninth Circuit panel addressed the question "whether the duty more broadly requires an insurer to effectuate settlement when liability is reasonably clear, even in the absence of a settlement demand. For several reasons, we conclude that it does."58 But for other reasons, the court affirmed the judgment in favor of the insurer. $^{59}$

It seems that the California courts had never clearly resolved the question whether the insurer had to take the initiative, and the Ninth Circuit's dictum, quoted above, provoked an uproar and a petition for rehearing even though the insurer ultimately won. ${ }^{60}$ Eventually, the Ninth Circuit withdrew its original opinion and affirmed in a chaste opinion that avoided addressing the issue. ${ }^{61}$

\footnotetext{
52. Yan Fang Du v. Allstate Ins. Co., 681 F.3d 1118, 1120 (9th Cir.), amended and superseded by 697 F.3d 753 (9th Cir. 2012).

53. Id.

54. Id.

55. Id.

56. Id. at 1121.

57. Id.

58. Id. at 1123.

59. Id. at 1127.

60. See Ben Adlin, 9th Circuit's Insurance Case Reversal Leaves Lawyers Dizzy, S.F. DAILY J., Oct. 24, 2012, at 1 (describing controversy resulting from Ninth Circuit's initial opinion).

61. Yan Fang Du v. Allstate Ins. Co., 697 F.3d 753, 758 (9th Cir. 2012).
} 
This episode highlights both the distinctiveness and the sensitivity of the law regarding duties of insurers in essence to "cooperate" to avoid exposing their customers to large claims. As one of the uninitiated, I certainly do not propose to venture onto the sort of legal thin ice that this Ninth Circuit panel encountered in attempting to clarify this body of law. Instead, I want only to emphasize that these difficult issues result from the singularity of the problem - a duty that almost requires the insurer to "bid against itself."

But there are additional singular, and sometimes controversial, cooperation aspects to the relationship between the insurer and the insured. Because it may have to pay (up to the policy limits) for the insured's torts, the insurer is protected by an obligation owed by the insured to cooperate in the defense of a case brought by somebody claiming to be the victim of actions covered by the policy. ${ }^{62}$ If the insured does not cooperate, the insurer is off the hook. ${ }^{63}$ Some regard this duty of the insured to be comparable to the duty of the insurer to defend, ${ }^{64}$ and it has been implied in insurance policies in which it is not affirmatively stated. ${ }^{65}$ As a general rule, this obligation to cooperate extends to assisting the insurer in investigation and settlement of the claim and in the defense of the claim if the insurer is providing it. ${ }^{66}$ But the failure of the insured to satisfy the obligation does not always relieve the insurer of its duty to defend or indemnify. ${ }^{67}$

As the Ninth Circuit discovered, charting these waters is hazardous. For our purposes, it suffices to recognize that dealing with cooperation in this specialized area is an ongoing challenge for the courts. Prescribing cooperating more broadly would undoubtedly magnify the challenge.

62. Monique M. Fuentes \& William D. Burger, The Practical Impact of an Insurance Policy's "Cooperation Clause" on an Insured and Its Insurance Carrier, DRI TODAY, Oct. 14, 2011, http://dritoday.org/feature.aspx?id=179.

63. See id. (stating that most courts will approve an insurer's denial of coverage following breach of the Cooperation Clause if insurer can show prejudice, and some courts approve denial without a show of prejudice).

64. See Douglas R. Richmond, An Overview of Insurance Bad Faith Law and Litigation, 25 SETON HALL L. REV. 74, 122 (1994) (arguing that the insured has a duty to cooperate with regard to an insurance claim that is as stringent as the insurer's duty to defend). But see Kransco v. Am. Empire Surplus Lines Ins. Co., 2 P.3d 1, 15-16 (Cal. 2000) (holding that the insured is not subject to a comparative fault for failure to cooperate in suit for bad faith conduct by the insurer).

65. 14 LEE R. RUSS ET AL., COUCH ON INSURANCE § 199:3 (3d ed. 1995).

66. See Principles of the LAW of Liability Insurance 39 (Am. Law Inst., Preliminary Draft No. 5, Aug. 24, 2012).

67. See id. at 40. 
[Vol. 61

\section{Contractual Duties To Negotiate}

The insurance situation at least involves parties that have entered into a contract; it is understandable that they may have some duties to each other. But how about parties that have not reached such an agreement? Gradually, the notion that liability could be posited on conduct during negotiations that actually never led to a formal and final contract gave rise to the possibility of a general obligation to negotiate in good faith-something like cooperation. A prominent example (often displayed in casebooks) is Hoffman v. Red Owl Stores, Inc., ${ }^{68}$ in which the Wisconsin Supreme Court held that a prospective franchisee could recover from a franchisor, even though their negotiation of a franchise agreement ultimately fell through, because it had led him into various moves that caused him losses. ${ }^{69}$ In essence, the court adopted a promissory estoppel theory. In 1969, Professor Knapp wrote a seminal article on the subject. $^{70}$

This has not served as a fount for a more general duty to cooperate or deal in good faith. For example, a generation ago Dean Perschbacher forecast that those special features bore on an expansion he expected of lawyers' possible duties to nonclients:

One such change is an expansion of the duty to bargain in good faith. Currently this obligation is restricted to labor negotiations and insurance, both highly regulated because of perceived special public interests. Most of the elements that comprise good faith bargaining in labor and insurance negotiations are either common to all negotiations, such as the proscription against misrepresentation, or are uniquely dependent on the substantive context, such as mandatory bargaining topics in labor law. Thus labeling them part of good faith bargaining does not carry any implications for a general fairness good faith principle in negotiations.

More generally, Professor Farnsworth reported in 1987 that American courts have been very cautious about finding that parties have duties to negotiate agreements in good faith in the absence of some special fiduciary obligation. Although there are a few examples in which courts have imposed liability for what seemed almost deceptive

68. 133 N.W.2d 267 (Wis. 1965).

69. Id. at 275 .

70. See Charles L. Knapp, Enforcing the Contract to Bargain, 44 N.Y.U. L. REv. 673 (1969).

71. Rex R. Perschbacher, Regulating Lawyers' Negotiations, 27 ARIz. L. REV. 75, 134-35 (1985). 
negotiation tactics that induced costly reliance by the other party to the negotiations, in general they have been felt to be free to break off their negotiations at any time and for any reason. As Professor Farnsworth explains:

Some scholarly writers... argue that a general obligation of fair dealing may arise out of the negotiations themselves, at least if the disappointed party has been led to believe that success is in prospect. Thus Summers wrote that if courts follow Red Owl, "it will no longer be possible for one party to scuttle contract negotiations with impunity when the other has been induced to rely to his detriment on the prospect that the negations will succeed.” American courts, however, have been unreceptive to these arguments and have declined to find a general obligation that would preclude a party from breaking off negotiations, even when the success was in prospect. ${ }^{72}$

Thus, although there are cases that recognize and enforce a contractual agreement to bargain in good faith, ${ }^{73}$ others remain skeptical about the notion. ${ }^{74}$ Even when they entertain the notion that such a contract may be enforceable, courts may often conclude that there has been no proof that the party who refused to go forward acted in bad faith. ${ }^{75}$ Further, when presented with "agreements to agree," most courts have balked at finding in such a nebulous contractual undertaking an obligation enforceable in court. ${ }^{76}$ This caution may be a signal about the utility of cooperation in the litigation setting.

72. E. Allan Farnsworth, Precontractual Liability and Preliminary Agreements: Fair Dealing and Failed Negotiations, 87 CoLUM. L. REV. 217, 239 (1987) (quoting Robert S. Summers, "Good Faith" in General Contract Law and the Sales Provisions of the Uniform Commercial Code, 54 VA. L. REV. 195, 225 (1968)); see also Knapp, supra note 70, at 673.

73. See, e.g., Brown v. Cara, 420 F.3d 148 (2d Cir. 2005); Copeland v. Baskin Robbins U.S.A., 117 Cal. Rptr. 2d 875 (Cal. Ct. App. 2002).

74. See, e.g., Ohio Calculating, Inc. v. CPT Corp., 846 F.2d 497, 501 (8th Cir. 1988) (finding written agreement calling for "good faith negotiations" was "unenforceable and unremediable agreement to negotiate”); Racine \& Laramie, Ltd. v. Cal. Dep’t of Parks \& Recreation, 14 Cal. Rptr. 2d 335 (Cal. Ct. App. 1993) (holding that the commencement of negotiations in and of itself does not create a duty to bargain in good faith).

75. See, e.g., Venture Assoc. Corp. v. Zenith Data Sys. Corp., 96 F.3d 275, 279 (7th Cir. 1996) (holding defendant free to negotiate for new terms not covered in letter of intent so long as it "was not trying to scuttle the deal”); IDT Corp. v. Tyco Grp., 918 N.E.2d 913, 917 (N.Y. 2009) (the parties negotiated about open terms for almost three years, and there was no evidence either party failed to act in good faith).

76. Farnsworth, supra note 72, at 263-64. 


\section{The Duty to Mediate in Litigation}

Parties might by their negotiations have induced detrimental reliance that would justify compensation, but it would seem that litigants who already have a dispute pending in court are in a different situation. Yet increasingly courts are expecting and sometimes demanding that parties before them negotiate about settlement. Can they insist that the parties be reasonable and cooperative in those negotiations? Can insisting on one's day in court be regarded as unreasonable and uncooperative, leading to adverse action by the judge?

In at least one context, cooperation can, in a sense, be compelled. Proposed class-action settlements can be approved by the court over the objections of class members. The court may do so only if satisfied that the settlement is "fair, reasonable, and adequate."77 Dissenting class members have a right to object, ${ }^{78}$ and they may appeal if the settlement is nonetheless approved. ${ }^{79}$ But even very substantial opposition within the class does not doom the settlement. ${ }^{80}$ As the Second Circuit put it:

[M]ajority opposition to a settlement cannot serve as an automatic bar to a settlement that a district judge, after weighing all the strengths and weaknesses of a case and the risks of litigation, determines to be manifestly reasonable. Preventing settlement in such circumstances not only deprives other class members of the benefits of a manifestly fair settlement and subjects them to the uncertainties of litigation, but, in this case, would most likely have resulted in the eventual disappointment of the objecting class members as well. ${ }^{81}$

Class actions are, however, a striking exception to the general rule that the client controls the decision of whether to settle; judicial paternalism is not usually the order of the day. But that principle often gives way - to the lawyers' and the parties' advantage- to the reality that settlements can offer desirable outcomes superior to the uncertainties and risks of litigation. ${ }^{82}$ Courts-under prompting by Congress-

77. FED. R. CIV. P. 23(e)(2).

78. Id. 23(e)(5).

79. Devlin v. Scardaletti, 536 U.S. 1, 14 (2002).

80. See, e.g., Cotton v. Hinton, 559 F.2d 1326, 1331, 1334 (5th Cir. 1977) (approving settlement despite objections of almost fifty percent of the class).

81. TBK Partners, Ltd. v. W. Union Corp., 675 F.2d 456, 462-63 (2d Cir. 1982).

82. See generally Samuel Issacharoff \& Robert H. Klonoff, The Public Value of Settlement, 78 FORDHAM L. REV. 1177, 1202 (2009) ("[A]ll citizens are better off for the prospect of a secure, if imperfect, system of compensation and deterrence. Trials are ... a small part of that balance.”). 
increasingly press parties to discuss settlement early and seriously. ${ }^{83}$ That is desirable. ${ }^{84}$

But the sticking point is whether courts can insist that parties bring a cooperative attitude to these sessions, and how exacting they can become about the cooperativeness of that attitude. On one level, the rules explicitly permit the court to require that parties be present or available "to consider possible settlement." ${ }^{85}$ But requiring that the parties settle seems to push beyond that frontier. If courts can insist that parties send somebody with authority to discuss settlement, can they also insist on settlement on terms the judge deems satisfactory, and can the judge impose sanctions for refusal to accept terms that judge deems satisfactory?

Giving certain answers to these questions is difficult or impossible, but that difficulty suggests the perils of insisting too energetically on cooperation to settle lawsuits. Consider a medical malpractice case in which a nonbinding summary jury trial led to an award of $\$ 200,000$, and plaintiff then agreed to settle for $\$ 175,000$, but the attorney for the defendant doctor's insurer was not authorized to go above $\$ 125,000 .^{86}$ The judge then ordered defense counsel to come to a settlement conference with "someone who can enter into a settlement in this range without having to call anyone else., ${ }^{\circ 7}$ But the adjuster who attended the settlement conference told the judge that her instructions from the home office were to repeat the prior offer "and not to bother to call them back if it were not accepted." ${ }^{88}$ The judge found that the insurer had deliberately refused to obey a court order, entered defendant's default, and set an Order to Show Cause hearing regarding criminal contempt by the insurer. ${ }^{89}$ Though this case does not go so far as to insist that parties behave as judges deem cooperative, ${ }^{90}$ some may regard it as coming close.

83. See FED. R. CIV. P. 16(a)(5) (allowing courts to order pretrial conferences for the purpose of facilitating settlement).

84. See generally Issacharoff \& Klonoff, supra note 82, at 1195-98 (arguing that most claimants are more interested in compensation via settlement than formal legal vindication in court, and that the compensation they receive serves a societal interest in deterring wrongful behavior).

85. FED. R. CIV. P. 16(c)(1).

86. Lockhart v. Patel, 115 F.R.D. 44, 45 (E.D. Ky. 1987).

87. Id.

88. Id.

89. Id.

90. Consider the analysis in Edward Sherman, Court-Mandated Alternative Dispute Resolution: What Form of Participation Should Be Required?, 46 SMU L. REV. 2079, 2107-08 (1993), regarding the malpractice case described in text: 
Should judges insist on settlement on their terms, or at least on terms they deem "fair, reasonable, and adequate," Second Circuit has said, "Although the law favors the voluntary settlement of civil suits, it does not sanction efforts by trial judges to effect settlements through coercion.... In short, pressure tactics to coerce settlement simply are not permissible."

In terms of cooperation, perhaps the most difficult question arises with the litigant that insists it will not settle. Consider the reaction of a judge to such a position from Wal-Mart:

Because Wal-Mart's asserted "no settlement" litigation policy will require the Court to expend substantial judicial time and resources in a trial which might have been avoided if Wal-Mart had been willing to engage in meaningful settlement negotiations, the Court finds that it would be just to require the attendance at trial of Wal-Mart's general counsel or some other Wal-Mart corporate officer with litigation policy authority.

The Court recognizes that a party has the right to refuse to offer any money for settlement in a given case and the court cannot require a party to make a monetary settlement offer in any given case. (Indeed, one might find it refreshing for a party to take a "principled stand" against settlement in a given case.) However, in the Court's view, an across-the-board policy of refusing to negotiate frustrates both the letter and spirit of both the Federal Rules of Civil Procedure and this Court's

Lockhart is an appropriate fact situation for sanctions. Defendant's refusal to send a representative with any settlement authority at all, other than to reiterate the previous offer, insured that the conference would be a futile proceeding. Requiring settlement authority does not coerce a party into settling for any specific amount, and litigant autonomy cannot justify ignoring a requirement directed at avoiding wasteful negotiation tactics.

The hard cases arise when the representative's settlement authority is more ambiguous than in Lockhart. Assume that an insurance company sends a representative with authority to settle only up to $\$ 10,000$, on the basis that it has thoroughly reviewed the case and is convinced that there is no liability at all and, that, in any event, the reasonable damages are much smaller than that amount. Surely the company should not be required to give its representative authority to settle at a higher amount when it has concluded that there is no justification for doing so. But the key inquiry is what the representative's instructions are. If he is sent without authority to consider any settlement above $\$ 10,000$, this is essentially a "no authority" case as in Lockhart. A court should be entitled to require that the representative at least be open to hearing the arguments of the other side with the possibility of settling at any amount found to be persuasive, even though the representative understands that the company has evaluated the case as not worth more than $\$ 10,000$. If his authority and instructions are so limited that he is deaf to any persuasion, then he is not the proper representative with adequate authority that the court has ordered.

91. FED. R. CIV. P. 23(e)(1).

92. Kothe v. Smith, 771 F.2d 667, 669 (2d Cir. 1985). 
Local Rules, which encourage good faith settlement efforts in order to preserve scarce judicial resources. Here, the Court is, in fact, not even requiring Wal-Mart to engage in settlement negotiations. It is simply requiring Wal-Mart's General Counsel, or other responsible corporate officer, to be present for trial, as the Court believes that requiring the attendance of such a Wal-Mart official during trial could have a salutary effect in that the responsible officer would have an opportunity to observe first-hand the effect of the company's policy both on the Court in general and in a particular case. Certainly, if this policy is important enough for Wal-Mart to persist in, then it is not asking too much for a responsible corporate officer to be present for trial. ${ }^{93}$

One could regard this education session for the Wal-Mart official as verging on coercion, but it is not a legal command to be reasonable or cooperative in relation to settlement of this case. As Professor Molot has argued, judges promoting settlement are moving furthest from their judicial role. ${ }^{94}$ The deeper the judge gets into the merits of the settlement in a command role (as opposed to an advisory role), the greater the difficulty of identifying legal grounds for her positions.

\section{E. Summary}

This discussion should illustrate that the judicial experience with enforcing a duty to cooperate has not been entirely satisfactory. There seems inevitably to be considerable difficulty determining when those whose interests stand in tension cross a line by taking unreasonable positions instead of cooperating with their adversaries. A part of the court-annexed ADR repertoire is the appreciation that negotiation alone is not sufficient to resolve disputes. One can push hard for settlement, but not too hard; parties do have a right to come to court for a decision.

But there surely are myriad topics on which parties might cooperate in the conduct of litigation even if they cannot agree on the ultimate resolution. Are those different? Consider the thoughts of a recently appointed Magistrate Judge in the Northern District of California:

[L]awyers do advocate for their clients-fight about deadlines and where the deposition should take place. Things like that, that I think to people who have not been involved in civil litigation before can seem petty. But I know from having done civil litigation, sometimes those

93. Shedden v. Wal-Mart Stores, Inc., 196 F.R.D. 484, 486 (E.D. Mich. 2000).

94. Jonathan T. Molot, An Old Judicial Role for a New Litigation Era, 113 YALE L.J. 27, 43 (2003) ("The most controversial of all judicial management tools-the judicial settlement conference-is the one that strays furthest from the judiciary's traditional adjudicative role.”). 
seemingly small fights end up being an essential part of the eventual outcome of the case. So I understand. ${ }^{95}$

Contrast those thoughts with the views of another recently appointed Magistrate Judge in the same court, who wished that "experienced attorneys would be a bit more proactive based on their experience in resolving disputes":

I would think a more experienced attorney would work a little bit harder to try to resolve the dispute. And sometimes they do, but then maybe they're dealing with someone else who just won't work with them and there's nothing that they can do, at that point, except seek court intervention. Now and then, you'll see a more experienced attorney and I'll think, "I know you've done lots of these and you know how it's likely to turn out, so, you can bring some more realistic perspective to the table when you meet and confer.” I would like to see them work a little bit harder towards resolving their own disputes. ${ }^{96}$

The problem, then, is to determine how the courts should approach these kinds of issues. There is likely no legal rule that precisely resolves such disputes. Should the lawyers be commanded to cooperate in resolving them? Would the judge be doing his job if he announced that on such matters, in the absence of an agreement, he would simply pick the position he regarded as most reasonable, and not split the baby? That might be a practical lever to prompt cooperation - fear the judge would opt for the other side's proposal as slightly more reasonable.

At least it seems we have reached the heartland of appropriate judicial insistence on lawyer cooperation. Here, the backstop of that insistence is that the judge ultimately has clear authority, indeed responsibility, to decide. We might say the hypothetical judge was shirking a duty to decide under the law by instead picking the less unreasonable position in the discovery dispute, but that seems to insist on too much law about what arrangements should be employed in discovery in a given case. Seeking cooperation is a valuable adjunct to the authority to decide, but for our purposes the key point is that the authority exists. Particularly in relation to matters on which an agreed protocol is superior to one imposed by judicial fiat, the judge should have authority to insist on cooperation. In that way, the key issues about

95. Technology Is Great, But Have a Backup Plan (interview with Hon. Nathanael Cousins), S.F. RECORDER, May 7, 2012, at 8.

96. Don't Throw In the Towel on Discovery (interview with Hon. Kandis Westmore), S.F. Recorder, Nov. 6, 2012, at 11. 
procedural cooperation are qualitatively different from the ones surveyed in this section.

\section{AMERICAN PROCEDURAL COOPERATION COMMANDS}

The German procedure code "imposes on parties a duty of cooperation in clarifying the issues in the case." ${ }^{\text {"9 }}$ Section 1 of the Korean Civil Practice Act "imposes on the parties a duty to cooperate in good faith."98 There has been at least some discussion of adding a comparable cooperation plank to Rule 1 of the Federal Rules of Civil Procedure, but misgivings have also been expressed that this sort of provision would be more likely to invite conflict than to prompt actual cooperation.

Rules commanding cooperation have appeared, however, in a number of places. In San Francisco, for example, the Northern District of California recently adopted Guidelines for the Discovery of Electronically Stored Information. ${ }^{99}$ The second General Guideline is entitled "Cooperation":

The Court expects cooperation on issues relating to the preservation, collection, search, review, and production of ESI. The Court notes that an attorney's zealous representation of a client is not compromised by conducting discovery in a cooperative manner. Cooperation in reasonably limiting ESI discovery requests on the one hand, and in reasonably responding to ESI discovery requests on the other hand, tends to reduce litigation costs and delay. The Court emphasizes the particular importance of cooperative exchanges of information at the earliest possible stage of discovery, including during the parties' Fed. R. Civ. P. 26(f) conference. ${ }^{100}$

The local rules of the District of Maryland similarly invoke the goals of Rule 1-just, speedy, and inexpensive conduct of discovery-and add: "The parties and counsel have an obligation to cooperate in planning and conducting discovery to tailor the discovery to ensure that it meets these objectives." ${ }^{101}$ The local rules of the Southern and Eastern Districts of

97. MAXEINER, supra note 1 , at 177.

98. Id. at 198.

99. Court Adopts New E-Discovery Guidelines Effective November 27, 2012, U. S. DISTRICT CT. N. DISTRICT OF CAL., http://www.cand.uscourts.gov/news/101 (last visited Feb. 6, 2013).

100. GUIDELINES FOR THE DisCOVERY OF ELECTRONICALLY STORED INFORMATION § 1.02 (N.D. Cal. 2012).

101. D. MD. R. app. A. See also Mancia v. Mayflower Textile Servs. Co., 253 F.R.D. 354, 357-58 (D. Md. 2008) (explaining the duty to cooperate). 
New York say much the same thing. ${ }^{102}$ The Sedona Cooperation Proclamation emphasizes the same sort of impulse. ${ }^{103}$ Something like 100 judges have signed on. ${ }^{104}$ Surely many other examples exist.

Without a cooperation provision in Rule 1, the Federal Rules of Civil Procedure nonetheless urge or require behavior that could be called cooperative in a number of places:

(1) Rule 26(f) directs the parties to confer early in the case, and contains several provisions that direct cooperation, at least as compared to the "trial by ambush" ethos of Roscoe Pound's day.

(2) The parties must "consider the nature and basis of their claims and defenses and the possibilities for promptly settling or resolving the case."

(3) The parties must "discuss any issues about preserving discoverable information., 106

(4) The parties must "attempt[] in good faith to agree on [a] proposed discovery plan.”107

(5) The discovery plan must include a wide variety of details, including the subjects on which discovery is needed, any issues about ediscovery, and any issues about preserving privilege. ${ }^{108}$

(6) Rule 16(f)(1)(B) authorizes sanctions against a party or attorney who "does not participate in good faith" in a pretrial conference. ${ }^{109}$

(7) Rule 37(a)(1) requires that a motion to compel discovery be supported by a certification "that the movant has in good faith

102. See S.D.N.Y. \& E.D.N.Y. R. 26.4. Local Rule 26.4 provides:

(a) Counsel are expected to cooperate with each other, consistent with the interests of their clients, in all phases of the discovery process and to be courteous in their dealings with each other, including in matters relating the scheduling and timing of various discovery procedures.

(b) Discovery requests shall be read reasonably in the recognition that the attorney serving them generally does not have the information being sought and the attorney receiving them generally does have such information or can obtain it from the client.

103. See The Sedona Conference Cooperation Proclamation (2008), available at https://thesedonaconference.org/cooperation-proclamation.

104. Id.

105. FED. R. CIV. P. 26(f)(2).

106. Id.

107. Id.

108. Id. 26(f)(3).

109. Id. 16(f)(1)(B). 
conferred or attempted to confer... in an effort to obtain [the desired discovery] without court action.,

(8) Rule 16(a) authorizes the court to order pretrial conferences for various purposes including "discouraging wasteful pretrial activities" and "encouraging settlement."11

(9) Rule 16(c)(1) commands each party to "authorize at least one of its attorneys to make stipulations and admissions about all matters that can reasonably be anticipated for discussion at a pretrial conference." $^{\prime 12}$ Rule 16(c)(2) lists fifteen categories of topics suitable for discussion at such a conference, and then adds that such a conference may also consider "facilitating in other ways the just, speedy, and inexpensive disposition of the action.,"113

(10) Rule 11(b)(1) makes an attorney's signature on a filing in court a certification that the positions he takes are "not being presented for any improper purpose, such as to harass, cause unnecessary delay, or needlessly increase the cost of litigation."114

Taken together, these provisions might appear to empower an American judge to insist on something approaching what the German or Korean judge expects in the way of cooperation. But when she insists on cooperation on these topics, the judge is not entering into the sorts of difficulties presented by the examples in Part II. How often is the place or time of a deposition a matter of real moment? How often might posturing about such things reflect a strategy to achieve litigation advantage? Perhaps it is true, as the magistrate judge quoted above suggests, that knock-down, drag-out fights about such topics actually achieve such importance that they end up driving settlement or other resolution. ${ }^{115}$

But should courts be patient with such posturing? Frankly, it is likely that the posturing will vanish or at least recede in the presence of the judge. Indeed, the difference in demeanor of counsel when the judge is there to watch is sometimes very striking. One possible solution to that problem is for judges to be more available to address mundane discovery matters like time and place of a deposition. It is certainly said

110. Id. 37(a)(1). A similar requirement appears in Rule 37(d)(1)(B) even though that provision applies only in situations in which the other side has completely failed to respond to the discovery.

111. Id. 16(a).

112. Id. 16(c)(1)

113. Id. 16(c)(2).

114. Id. 11(b)(1)

115. See supra text accompanying note 95 (quoting recently appointed Magistrate Judge). 
that judges who do make themselves available actually have to resolve very few discovery disputes. Somehow cooperation occurs before the matter must be presented to the judge. Indeed, many lawyers call this sort of judicial behavior "adult supervision."

Why can't lawyers behave like adults when the judge is not there? Most can and do. Perhaps that behavior is more prominent in litigation in which the lawyers deal with one another regularly than litigation involving lawyers who have no track record with one another. That might explain why, despite the tendency mentioned above of criminal defense counsel to exploit everything they can use to frustrate the prosecution, judges often report that the lawyers in their criminal cases are much more cooperative than litigators in civil cases.

Perhaps that behavior also reflects client preferences or imperatives in criminal litigation more frequently than in civil litigation. For a variety of reasons, clients in civil cases may want to game the system as long as possible. For a variety of reasons, they may regard devious activity as the service lawyers provide, and expect to get their own share. ${ }^{116}$ For a variety of reasons, parties do not readily take account of the weaknesses in their cases, or the strengths in the other side's case; that is one of the reasons for judges to insist that the clients show up for settlement conferences. Perhaps clients who are prone to fighting over everything and other forms of misbehavior look for and find lawyers for whom that is the modus operandi; at some point it is permissible to punish the client for what the lawyer did because the client selected the lawyer. $^{117}$

No doubt zealous representation would be at least an excuse for obstructive or disruptive lawyer behavior in situations in which the real reason is less savory. At a minimum, judges can expect that lawyers will not succumb to the temptation to use impolite or overbearing tactics. They can try to inspire cooperation as well, without lowering the boom as authorized by the many rules listed above. Probably the way judges can further this goal is diligent case management. More than thirty years ago, Judge Peckham, one of the pioneers in the case management movement, stressed that holding an early case management conference (not then required by the Rules) "warns the attorneys that they have a

116. Consider, for example, the Jim Carey movie Liar Liar, about the lawyer who suddenly is prevented from telling a lie and finds he can't do his job. LIAR LIAR (Universal Pictures 1997).

117. See, e.g., Link v. Wabash R.R. Co., 370 U.S. 626, 633-34 (1962) ("Petitioner voluntarily chose this attorney as his representative in the action, and he cannot now avoid the consequences of the acts or omissions of this freely selected agent.”). 
vigilant judge," and alerts the judge to whether the case involves "a particularly combative attorney who, if the case is not actively managed during pretrial, might succeed in turning a trial that should be a molehill into a mountain." 118 This technique is much more widespread now, and it still should work.

One analogy that comes to mind is the labor law notion of mandatory topics of negotiation. ${ }^{119}$ When a judge tells the parties to negotiate a regime for electronic discovery, in effect the judge is doing what the Rules expect. The Rules themselves cannot prescribe the details of a discovery regime for an individual case, and a judge is also ill-equipped to do so. There are, in short, some things that judges should be able to insist that lawyers do to make the litigation system work. They should not have to insist; indeed, the Rules often already direct the lawyers to do these things. Rule 26(f) instructs the lawyers to discuss e-discovery and preservation; it is not simply up to them. ${ }^{120}$ Even when the Rules are not so direct, it would be odd to say the judge may not insist on cooperation. And they are beginning to do so. Consider the clarion call in 2009 by a Federal Judge in New York:

This Opinion should serve as a wake-up call to the Bar in this District about the need for careful thought, quality control, testing, and cooperation with opposing counsel in designing search terms or "keywords" to be used to produce emails or other electronically stored information ("ESI"). While this message has appeared in several cases from outside this Circuit, it appears that the message has not reached many members of our Bar.

An abstract requirement of cooperation, on the other hand, seems less suited to achieving practical results. There certainly has been some discouraging recent history with efforts by rule to encourage improved lawyer behavior. The 1983 amendments to Rule 11 were intended in part to upgrade lawyer behavior, but were widely criticized for ushering in a decade of corrosive finger-pointing. ${ }^{122}$ A cooperation requirement

118. Robert F. Peckham, The Federal Judge as a Case Manager: The New Role in Guiding a Case from Filing to Disposition, 69 CALIF. L. REV. 770, 781-82 (1981).

119. See supra Part II.A.

120. FED. R. CIV. P. 26(f) (directing attorneys to discuss issues pertaining to preservation and formulate a discovery plan).

121. William A. Gross Constr. Assoc., Inc. v. Am. Mfrs. Mut. Ins. Co., 256 F.R.D. 134, 134 (S.D.N.Y. 2009)

122. See, e.g., Mark Spiegel, The Rule 11 Studies and Civil Rights Cases: An Inquiry into the Neutrality of Procedural Rules, 32 CONN. L. REv. 155, 157 (1999) (discussing the increase in Rule 11 litigation following the 1983 Amendment). 
might lead in a similar direction. But the unequaled latitude that American procedure-particularly broad discovery-confers on American lawyers surely makes cooperation on at least the details of discovery something that lawyers ought to ensure. The real question is not what they should do, but how to get them to do it.

\section{CONCLUSION}

Forty years ago, Judge Frankel proposed that we "consider whether the paramount commitment of counsel concerning matters of fact should be to the discovery of truth rather than to the advancement of the client's interest." "123 He suggested further that this inquiry led to the question "whether it would be an excessive price for the client to be stuck with the truth rather than having counsel allied with him for concealment and distortion."124 One might urge that the legal profession cooperate in pursuing this goal. But so far as I know, Judge Frankel's cooperative vision has found few enthusiastic takers in the bar. The era of Rambo litigation followed instead.

The cooperation judges seek now is not so aggressive, but results from their increasing role in providing adult supervision during the pretrial process, particularly with regard to discovery. True, childish behavior may actually be designed to conceal or distort-the sorts of things Judge Frankel wished lawyers would abjure. But more often, I suspect, it results from Rambo attitudes that are not so calculated. Parents do not want their children to be little Rambos, and judges increasingly resist that tendency among lawyers. Experienced litigators seem increasingly to acknowledge that Rambo tactics are not the only ones. Thus, in a large survey of lawyers in 2009, the Federal Judicial Center found that $90 \%$ either agreed or strongly agreed with the following statement: "Attorneys can cooperate in discovery while still being zealous advocates for their clients."125

The Sedona Cooperation Proclamation ${ }^{126}$ has emerged in this environment. Aspirational statements may sometimes seem toothless, but they can produce results. Maybe Sedona has it right in producing what is in large measure an aspirational endorsement of cooperation. At

\footnotetext{
123. Frankel, supra note 26, at 1055.

124. Id. at 1056 .

125. EMERY G. LeE III \& ThOMAs E. Willging, Federal Judicial CENTER National CASEBASED Civil Rules SuRvey 63, 104 (Fed. Jud. Center 2009).

126. See supra note 103 and accompanying text.
} 
some point, it takes two to cooperate. But it is also true that one or the other has to begin. Sometimes it takes an authority figure to break the ice.

Self interest is the best lubricant, and it may be that good lawyers will recognize that. More than twenty years ago, some lawyers began to appreciate the value of cooperation in discovery. Thus, the San Francisco Recorder featured a story entitled "Discovering Cooperation" about a prominent defense lawyer's novel approach to securities fraud suits. ${ }^{127}$ The example was a 1991 suit filed by the famed plaintiff's lawyer William Lerach against a high-tech client of this lawyer. ${ }^{128}$ Under the lawyer's guidance, the company "agreed in the stipulated order to produce relevant core documents and let plaintiff's lawyers interview a selected group of directors, officers, and employees." company turned over twenty to twenty-five boxes of documents and settled for an amount "in the lower range of payments" eighteen months after the suit was filed. ${ }^{130}$ It spent about half as much in attorney fees as it would have by defending in the conventional aggressive manner. The article asked whether this example heralded "a new trend"_- "[m]ore and more securities cases seem to be moving toward informal and cooperative discovery techniques."131 My contemporaneous 1994 handwritten note on the article was: "Will this ever work?"

At a general level, the experience of the last twenty years does not suggest that since 1994 most cases have gone in this new direction. But particularly in regard to the manifest challenges and burdens of ediscovery, more lawyers may be awakening to these possibilities. Consider the recent recommendations of a nationally renowned ediscovery lawyer about how to move to the newest darling technique of the area, predictive coding:

Whether a court smiles on a methodology may not be the best way to conclude it's the better mousetrap. Keyword search and linear review enjoy de facto court approval; yet both are deeply flawed and brutally inefficient.

The imprimatur that matters most is "opponent approved." Motion practice and false starts are expensive. The most cost-effective method

127. Mark Boennighausen, Discovering Cooperation, S.F. RECORDER, March 30, 1994, at 1.

128. Id.

129. Id.

130. Id. at 14 .

131. Id. 
is one the other side accepts without a fight, i.e., the least expensive method that affords opponents superior confidence that responsive and non-privileged material will be identified and produced.

Don't confuse that with an obligation to kowtow to the opposition simply to avoid conflict. The scenario I'm describing is a true winwin ....

These sorts of issues are likely to be a prime focus of good lawyers.

Not all lawyers are good lawyers. Not all lawyers will see the light on issues like predictive coding. But rules to control the behavior of bad lawyers may not be an improvement. The 2006 e-discovery amendments to the Civil Rules, for example, largely rely on the parties (and the lawyers) to design sensible protocols for specific cases rather than prescribing specifics. ${ }^{133}$ Trying to provide those specifics was too difficult. $^{134}$ Specifics on cooperation would likely be more difficult yet to prescribe. Judges who see uncooperative lawyers impeding progress in cases before them have an array of formal (and many more informal) ways to respond to their erring ways. They probably cannot change the general culture of lawyering; if Rambo tactics are still frequent, individual judges likely cannot end them. But they can deal fairly effectively with them when they do see them. That is probably as much as rules of cooperation can ever aspire to do.

132. Craig Ball, Imagining the Evidence, S.F. RECORDER, Aug. 13, 2012, at 15, available at http://www.dailyreportonline.com/PubArticleDRO.jsp?id=1202566842609\&thepage=1.

133. See Richard L. Marcus, E-Discovery Beyond the Federal Rules, 37 U. BALt. L. Rev. 321, 342-43 (2008) (making this point).

134. I am here recalling the drafting work on those amendments, which extended over many years and explored a variety of possible specifics on topics that eventually were left to party agreement. 